\title{
Author Correction: DeepTCR is a deep learning framework for revealing sequence concepts within T-cell repertoires
}

\author{
John-William Sidhom (1), H. Benjamin Larman (1), Drew M. Pardoll \& Alexander S. Baras (1)
}

Correction to: Nature Communications https://doi.org/10.1038/s41467-021-21879-w, published online 11 March 2021.

The original version of this Article omitted the following funding information from the Acknowledgements: “The research was supported by the Bloomberg Kimmel Institute for Cancer Immunotherapy, The Mark Foundation for Cancer Research, philanthropy of Susan Wojcicki and Dennis Troper in support of Computational Pathology at Johns Hopkins, the Johns Hopkins - Bristol Myers Squibb Immuno-Oncology Consortium, and the NIH Cancer Center Support Grant”.

Additionally, the original version of this Article omitted a reference to previous work in 'Tickotsky N, Sagiv T, Prilusky J, Shifrut E, Friedman N. McPAS-TCR: a manually curated catalogue of pathology-associated T cell receptor sequences. Bioinformatics. 33, 2924-2929 (2017)'. This has been added as reference 40 at the fourth sentence of the Results section 'Supervised regression allows identification of antigen-specific TCRs in single-cell data': 'To independently validate whether these models trained on single-cell data learned salient antigen-specific features of the immune response, we collected experimentally validated CDR3 $\beta$ sequences from the McPAS-TCR database ${ }^{40}$ for Flu-MP (influenza derived), BMLF1 (EBV derived), and MART1 (melanoma derived) epitopes and applied the respective models trained on the 10x Genomics dataset on these TCRs'. These errors have been corrected in the PDF and HTML versions of the Article.

Published online: 13 April 2021

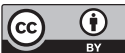

Open Access This article is licensed under a Creative Commons Attribution 4.0 International License, which permits use, sharing, adaptation, distribution and reproduction in any medium or format, as long as you give appropriate credit to the original author(s) and the source, provide a link to the Creative Commons license, and indicate if changes were made. The images or other third party material in this article are included in the article's Creative Commons license, unless indicated otherwise in a credit line to the material. If material is not included in the article's Creative Commons license and your intended use is not permitted by statutory regulation or exceeds the permitted use, you will need to obtain permission directly from the copyright holder. To view a copy of this license, visit http://creativecommons.org/licenses/by/4.0/.
}

(C) The Author(s) 2021 